\title{
Типи референції у висловленнях осуду
}

\author{
Ю. В. Коваленко \\ Харківський національний педагогічний університет імені Григорія Сковороди, м. Харків, Україна \\ Corresponding author. E-mail: yulia1001k@gmail.com
}

Paper received 28.01.20; Accepted for publication 14.02.20.

\section{https://doi.org/10.31174/SEND-Ph2020-217VIII65-07}

Анотація. У статті визначено та проаналізовано типи референції об'єкта осуду в текстах мас-медіа. Виходячи із соціальнопсихологічних критеріїв девіантності виділено та проаналізовано типи референції предмета осуду. На прикладах 3 текстів сучасних українських інтернет видань досліджено мовні одиниці, що репрезентують експліцитну та імпліцитну референцію. Також розглянуто синтаксичні засоби, що можуть вживатися у висловленнях осуду.

Ключові слова: типи референції, осуд, медіа-текст, експлічитна референція, імплічитна референція.

Вступ. Дослідження сучасної лінгвістичної науки спрямовані на вивчення особливостей використання мовних одиниць у різних типах текстів. Унаслідок стрімкого розвитку інформаційних технологій і процесів глобалізації інтенсивного вивчення набули медіа-тексти.

Мас-медіа висвітлюють актуальні проблеми, надають інформацію щодо політичних, соціальноекономічних, культурних подій, впливають на громадську думку, певним чином оцінюючи події. Негативна ж оцінка виражається через осуд подій та явищ, що супроводжують життя соціуму.

Висловлення осуду передають негативне оцінне ставлення мовця до адресата, виражають реакцію мовця на невідповідність об'єкта оцінки певним нормам і оцінним стереотипам, що існують у свідомості суб'єкта оцінки.

Референція є важливим явищем для дослідження висловлень осуду в сучасній українській публіцистиці, оскільки дуже часто мовні одиниці, які ідентифікують і характеризують, використовуються в мові як засіб вираження емоційно-оцінних значень. Відображаючи у свідомості людини об'єкти, явища і події навколишньої дійсності, ці одиниці забезпечують смисловий зв'язок, цілісність, інформативність, комунікативність і прагматичність медійних текстів.

Стислий огляд публікацій за темою. Теорія референції виникла в рамках філософії та логіки XX століття, і була започаткована роботами Дж. Мілля, Г. Фреге, Б. Рассела, Р. Карнапа, А. Тарського. Значну роль для розвитку теорії відіграли студії Н. Арутюнової, Т. Булигіної, А. Шмельова, В. Виноградова та ін. Наразі ми спостерігаємо виникнення нових підходів в аналітичній філософії та становлення теорії лінгвістичної референції. Виділяють такі концепції референції, як семантична теорія, до якої наближаються теорії Г. Фреге та Дж. Серля, теорія дескрипцій Б. Рассела, номінативна, як наприклад каузативна теорія С. Кріпке, і дейктична (концепція Д. Каплана ).

Дискурсивний підхід, започаткований роботами М. Кронгауза, О. Ревзіна, П. Стросона, Я. Хінтікка та панівний в сучасній лінгвістиці також вплинув на дослідження референції, змістивши акценти дослідження 3 референції в межах окремого речення, на референцію в межах фрагменту тексту або цілого тексту. Це робить можливим дослідження характеристик адресанта й адресата, інтенцію висловлення, комунікативну ситуацію, модальність одного висловлювання і цілого тексту.

Теорію референції в прагматичному аспекті досліджували Л. Лінський, Жд. Серль, Жд. Остін, П. Стросон, О. Падучева. Так, Жд. Серль трактував референцію як відношення між наміром мовця і впізнаванням цього наміру адресатом [15].

Серед останніх розвідок слід згадати I. Панченко, яка вивчала імпліцитну адресатну референцію, та С. Терехову, яка дослідила референцію в системі орієнтаційних репрезентацій.

Мета статті передбачає визначення та аналіз типів референції у висловленнях осуду в сучасній українській публіцистиці.

Матеріалом дослідження стали тексти таких інтернет-видань, як «Українська правда» та «Український тиждень»

Результати та їх обговорення. Бурхливий розвиток теорії референції призвів до того, що саме визначення референції є досить дискусійним.

За визначенням Н. Арутюнової: «Референція співвіднесеність актуалізованих (включених у мовлення) імен, іменних виразів (іменних груп) або їх еквівалентів до об'єктів дійсності (референтів, денотатів)» [1, с. 411].

Загнітко визначає референцію як процес співвідношення одиниць мовлення (іменників та іменної групи) 3 позамовною дійсністю, а також результат такого співвідношення [5, с. 40].

В нашому дослідженні ми дотримуємося визначення, запропонованого О. Селівановою, яка кваліфікує референцію як «відношення мовленнєвих одиниць до позначених ними об'єктів дійсності» та додає, що «референція поширюється не лише на номінативні одиниці, залучені до мовлення, а й на висловлення, тексти і є однією з передумов оцінки їхньої істинної чи неістинної природи відповідно до тих ситуацій, які вони позначають» [10, с. 77]. Саме відношення мовленнєвих одиниць різних рівнів до позначених ними об'єктів зазвичай і є вираженням осуду в текстах масмедіа, тобто саме називання об'єкта є виявом негативного, несхвального ставлення до адресата. 3 другого боку, референція у висловленнях осуду в публіцистичних текстах, як процес віднесення назв до реалій дійсності, виражається не тільки номінативними одиницями, в її механізмах часто беруть участь цілі висловлювання і тексти.

Досліджуючи комунікативну ситуацію висловлен- 
ня осуду можна виділити об'єкт осуду, суб'єкт і предмет. Під суб'єктом ми розуміємо особу або групу осіб, що висловлює осуд, тобто адресант. Об'єктом є адресат осуду. Предметом виступає те порушення норми, що спричинило осуд суб'єкта.

Позначення об'єкта і предмета осуду та, відповідно, надання будь-якої інформації про них, а відтак і дослідження неможливі без урахування законів референції.

Референцію об'єкта осуду можна розділити за такими типами:

1) Особистість. У цьому випадку осуджується одна особа, дії або бездіяльність якої викликали невдоволення мовця. Зазвичай, це публічна людина - політик, бізнесмен, громадський діяч, особа, діяльність якої привертає увагу суспільства. У висловленнях цього типу можуть вживатися слова та словосполучення, що виражають негативну оцінку чогось або когось, несхвалення, осуд, іронію чи презирство. Використовуються оцінні іменники: параметрично-оцінні (демінутиви та аугментативи) та емоційно-оцінні - емотиви (пейоративи), евалюативи та ескпресиви. Негативне ставлення мовця до осуджуваної ним особи часто виражається за допомогою стилістично зниженої лексики (вульгаризми, лайлива, обсценна лексика, дисфемізми). Референція такого типу вказує на одиничний ідентифікований об'єкт, а отже іменники, що використовуються для референції завжди в однині. Наприклад: "Путінська мерзота", "посібник терористів" - пишуть тележурналісту з Києва Володимиру Рунцю на його сторінці в соцмережах за те, що його прізвище виявили серед акредитованих в "ДНР" представників 3МI [8].

Негативну оцінку також реалізують метафорично вжиті імена реальних чи вигаданих осіб, дії яких, зазвичай, осуджуються суспільством. Наприклад: Він сподівається, що нас можна спокусити невичерпними можливостями бісівського російського «бєспрєдєла» - корупції та беззаконня... Марна річ, ВладіміреАдольфе Владіміровічу-Ало-їзовичу! Нічого у вас не вийде [6].

2) Соціальна група. У цьому випадку осуджується група осіб. Це може бути уряд країни, окрема політична партія, прошарок суспільства, певна спільнота чи угрупування людей об'єднаних за тою чи іншою ознакою. Для цього типу референції також характерно використання емоційно-оцінних іменників та зниженого стилю, однак референція такого типу вказує на групу ідентифікованих об'єктів, а отже іменники часто стоять в множині, або використовуються збірні іменники, наприклад: олігархія, клієнтура, партія, братва, наволоч, влада та ін.. Окрім іменників можуть використовуватися негативно-оцінні та емоційні прикметники, що характеризують осіб, на яких спрямовано осуд. Референт також може характеризувати відповідний предикат, що має семантику оцінки. Наприклад: "Зрадники Батьківщчини, поплічники терористів, колаборанти!" Що тільки не лунало в бік журналістів, акредитованих в самопроголошеній "Донецькій народній республіці", список з якими опублікував сайт "Миротворець" [8].

3) Явище. Референція цього типу називає негативні феномени, притаманні людському суспільству та реалізується абстрактними іменниками, що мають негативну конотацію, такі як: корупція, хабарництвво, зрада, зневага, жадібність та ін. Наприклад: "Болтон розкритикував Китай за "хабарництвво, укладання непрозорих угод та використання боргової політики, щоб зробити Африку заручницею бажань та вимог Пекіна", - пише "Голос Америки" [12].

Також для референції використовуються абстрактні іменники, що мають нейтральну конотацію: Перехід бізнесменів у політику хоча час від часу й трапляється, але масовим явищем скоріше не $\epsilon$, і часто викликає осуд [9]. У такому випадку від адресата потрібна спільна із адресантом соціокультурна компетенція, а також володіння певним обсягом знань у межах обговорюваного питання.

Оскільки для медіа-текстів характерна жива мова та яскрава експресивність, назви осуджуваних явищ часто творяться автором штучно за допомогою характерних для абстрактних іменників суфіксів: Явище "порохобоцтвв" стало водночас ганебним і показовим [11].

4) Процес. У цьому випадку осуджується послідовна зміна станів об'єкту, предметів та явищ, що відбувається закономірним порядком та послідовна в часі. Для цього типу характерне використання абстрактних іменників. Зазвичай такі іменники мають суфікси ння, -ація, -ізація і вказують на процеси формування, використання та зберігання чого-небудь або мають значення тривалої дії: маргіналізація, урбанізація, комунізація, мілітаризація. Крім того, референт може характеризуватися відповідними предикатами процесу, яким властива ознака динамічності, вони позначають динамічні явища в світі, кількісні та якісні зміни, що стосуються людини чи інших істот, різноманітні видозміни початкового стану предметів і речей. Наприклад: У преамбулі проекту йдеться про осуд "тимчасової окупащуї Російською Федерацією частини території України - Автономної Республіки Крим і міста Севастополя" і "невизнання iіi анексії" [13].

5) Подія. Осуджуються “миттєві” ситуації, причому слово миттєві не треба розуміти буквально: фізично така ситуація може відбуватися протягом певного проміжку часу, однак з погляду мови події нібито не мають тривалості і зводяться до точки на часовій осі, оскільки в них немає жодної проміжної фази. Загалом, більш чи менш категоричну оцінку здебільшого передають констатації-описи неправильно вчинених на думку адресанта дій. Висловлювання часто безособові, і наголос робиться передусім на самій дії. Також для референції цього типу характерно вживання мовних кліше із закріпленою в них негативною семантикою. Наприклад: ЄС засуджує будівництво Керченського моста без згоди України та називає його ще одним порушенням суверенітету і територіальної ияілісності України [3].

6) Предмет. Для такого типу висловлень характерний осуд неживого об'єкта. Це може бути річ, справа, предмет. Референція такого типу може реалізуватися будь-якими іменниками. Важливу роль у висловленнях цього типу відіграють дескрипції. Наприклад: Представник Росії Свген Загайнов заявив, що "проект є одностороннім", необ'єктивним $i$ упередженим. "Проект повністю ігнорує односторонні наслідки для 
жителів Криму від дій української влади", - сказав російський делегат [13].

Окрім референції об'єкта для висловлень осуду важливою $є$ також референція предмета осуду, оскільки в цьому випадку відбувається позначення та називання поведінки або вчинку, що викликали осуд. Виходячи із соціально-психологічних критеріїв девіантності виділяємо такі типи референції предмета:

1) Референція делінквентності. Називання вчинку, що $\epsilon$ протиправним відносно чинного законодавства конкретного суспільства, визнається кримінальним чи адміністративним порушенням. Позначається іменником злочин та його синонімами: злодіяння, проступок, правопорушення, праволомство, кримінал, кримінальщзина, лиходійство, харцизтво, злочинство; а також іменниками, що позначають різні типи злочинів: крадійство, вбивство, душогубство, вандалізм та ін.: Судячи зі слів у телеграмі, надісланій президентом РФ матері вбитого політика: "буде зроблено все, щоб організатори і виконавці підлого $і$ ичинічного вбивства понесли заслужене покарання", видається, що сам Путін це добре зрозумів, та чи не запізно [4].

2) Референція адиктивності. Для референції цього типу характерним $\epsilon$ називання тих речей, речовин або діяльності, характеристика станів, що можуть викликати адикцію та соціально осуджуються. Це може бути наркоманія, алкоголізм, паління, азартні та комп 'ютерні ігри, клептоманія та інше: "Хто посадив Україну на цүю голку, ви знаєте чудово. Вони теж перебувають і в цій залі. А те що ми зараз робимо, це називається лікування і реабілітація. Коли це закінчиться, ми зліземо з иієї голки", - заявив міністр [10].

3) Референція вад характеру. Для цього типу референції типовим $є$ позначення дій та вчинків, що спричинені недотриманням морально-етичних норм, нерозумінням індивідом або групою індивідів низки базових моральних категорій і ключових понять етики. Предмет осуду називається абстрактними іменниками - бездарність, безграмотність, характеризується негативними дескрипціями - несправедливий, непропориійний, найхитріший, найнахабніший; та відповідними предикатами: "Бездарність, безграмотність, керівництва Генеральної прокуратури приводить до того, що люди, які захищають українську Конституцію сьогодні, або піддані небезпеці, або помирають [14].

4) Референція вчинків, викликаних психічними патологіями. У цьому типі висловлень відбувається позначення дій, що можуть бути охарактеризовані як патологія психіки особистості. Сюди ж відносять осуд віктимної, інфантильної поведінки. Наприклад: У божевіллі ботоксного лідера давно ніхто не сумнівається. Загнаний у куток, без друзів, без однодумців, забезпечивши країні ізоляцію від цивілізованого світу та економічне гниття, він побудував у себе в голові власні світи, у яких йому якщо й не надто добре, то принаймні зрозуміло. [2].

5) Референція позитивних явищ або дій. Іноді вчинки особистості, здібності якої значно перевищують середньостатистичні, характеризуються обдарованістю, талантом та геніальністю, розглядаються суспільством як такі, що виходять за рамки звичного, нормального та традиційного, а отже викликають нерозу- міння і осуд. Крім того, осуду можуть зазнавати i явища, які загалом мають позитивний характер, однак у певних особистостей викликають негативні емоції. Оскільки такий осуд не характеризується негативним впливом на суспільство або конкретну особистість, не суперечить морально-етичним цінностям та не завдає шкоди, а в його основі позитивні явища, для референції цього типу характерним $€$ вживання лексики 3 позитивною конотацією, що поза контекстом репрезентує позитивну оцінку, проте у висловленні реалізує іронічне ставлення адресанта до дій, вчинків та характеристик адресата. Наприклад: 100\% відкидати будь-яку з вищезазначених версій, звичайно ж, не можна, адже про "витончені" політичні маневри Кремля ходить не одна легенда. Такі вже правила гри під назвою "велика політика" [7].

Характер актуалізації в розглянутих прикладах $\epsilon$ експліцитним. Однак аналіз матеріалу свідчить і про випадки імпліцитної референції в медійних текстах.

Імпліцитну референцію визначаємо як референцію, виведення якої за умов відсутності експліцитно виражених індикаторів відбувається на основі загального контексту, характеристик комунікантів, їхніх відносин та параметрів комунікативної ситуації. Серед індикаторів імпліцитної референції можна виділити лексичні засоби, серед яких переважають іменники та прикметники 3 нейтральною або позитивною конотацією, які вживаються в переносному значенні, або виражають іронію. Крім того, широко використовуються такі прийоми виразності, як метафора, метонімія, епітет, оксиморон. Негативно-емоційного забарвлення надають також непрямі звертання до адресата в 3-й особі чоловічого чи жіночого роду, чи навіть середнього роду, що виражає зневажливе та принизливе ставлення адресанта. Наприклад: Інтернет зріс за 10 років. Кількість майданчиків зростала пропорційно кількості каналів після початку Революції Гідності. Їх охоплення збільшилося, тому гідра цензури рушила туди [11].

Синтаксичні засоби - еліптичні та безособові конструкції - пасивний стан дієслова, інфінітивні звороти. Також вживаються риторичні запитання та окличні речення. Негативність оцінки та прагматику осуду при такому вираженні можна зрозуміти лише із загального контексту.

Висновки. Таким чином, оскільки для мас-медіа характерним $\epsilon$ оперативне реагування на злободенні суспільно-політичні, економічні та соціальні події, для референції у висловленнях осуду властиво вживання стилістично зниженої та емоційно-оцінної лексики, слів та словосполучень, що виражають негативну оцінку чогось або когось, несхвалення та осуд. Негативне ставлення мовця до осуджуваної ним особи також часто виражається за допомогою негативних дескрипцій та предикатів.

При імпліцитному вираженні осуду для розуміння тексту усі учасники комунікативної ситуації мають володіти певним обсягом знань, бути обізнані в ситуації.

Запропонована типологія референцій може бути використана для подальшого дослідження осуду, як мовленнєвого жанру, його параметрів та ознак, а також для розробки алгоритму прагматичного аналізу 
1. Арутюнова Н. Д. Референция/Лингвистический энциклопедический словарь/Гл. ред. В. Н. Ярцева. - М: Сов. энциклопедия, 1990. - С.411-412.

2. Бараба К. «Убивайте всіх — Господь своїх упізнає!» [Е. pecypc]. Український тиждень. 2018. Режим доступу: https://m.tyzhden.ua/column/221715

3. Декларація $\mathrm{CC}$ до 5-річчя анексії Криму: тверда підтримка України і вимоги до Росії [Е. ресурс]. Українська правда. $2019 . \quad$ Режим доступу: https://www.pravda.com.ua/news/2019/03/17/7209413/

4. Дрогомирецький Б. Нємцов і маріонетка [Е. ресурс]. Українська правда. 2015. Режим доступу: https://www.pravda.com.ua/columns/2015/03/3/7060316/

5. Загнітко А. П. Сучасні лінгвістичні теорії: Монографія. Вид. 2-ге випр. і доп. - Донецьк: ДонНУ, 2007. — 219 с.

6. Панченко В. Шевченко vs Путін. Параноя «визволительства» [Е. ресурс]. Український тиждень. 2014. Режим доступу: https://tyzhden.ua/Columns/50/104210

7. Петровець О. Найбільший страх Путіна стає реальністю [Е. ресурс]. Українська правда. 2017. Режим доступу: https://www.pravda.com.ua/columns/2017/03/29/7139629/

8. П'єцух М. Навіщо українські журналісти їздять в окупований Донбас? [Е. ресурс]. Українська правда. 2016. Режим https://www.pravda.com.ua/articles/2016/05/17/7108674/ доступу:

9. Про заробітну плату, або "Скупий платить двічі" [Е. pe-

\section{AТУРA}

сурс]. Українська правда. 2016. Режим доступу: https://www.pravda.com.ua/columns/2016/10/31/7125340/

10. Рева порівняв кредити МВФ із терапією для наркомана, [Е. ресурс]. Українська правда. 2018. Режим доступу: https://www.pravda.com.ua/news/2018/05/25/7181341/

10. Селіванова О. О. Сучасна лінгвістика: напрями та проблеми: підручник/О.О.Селіванова. - Полтава:Довкілля-К, 2008. - $712 \mathrm{c}$.

11. Солонько О. Як нас поглинає інформаційний відстійник [Е. ресурс]. Українська правда. 2018. Режим доступу: https://www.pravda.com.ua/columns/2018/12/21/7201899/

12. США оприлюднили план із протистояння РФ і Китаю в Африці [Е. ресурс]. Українська правда. 2018. Режим доступу: https://www.pravda.com.ua/news/2018/12/15/7201318/

13. Україна представила в ООН проект резолюції щодо Криму, РФ проти [Е. ресурс]. Українська правда. 2016. Режим https://www.pravda.com.ua/news/2016/11/9/7126227/

14. Шумілін О. Луценко в Раді наїхав на Соболєва: "Недоросль, у якого діарея мозку" [Е. ресурс]. Українська правда. 2018. Режим доступу: https://www.pravda.com.ua/news/2018/11/6/7197408/

15. Searle J. R. Reference as a speech act/J. R. Searle//Speech acts. An Essay of the Philosophy of Language - London: CUP, 1969a. - P. 77-96.
1. Arutyunova N. D. Reference/Linguistic Encyclopedic Dictionary/Ch. ed. V. N. Yartseva. - M: Sov. Encyclopedia, 1990. - P.411-412.

2. Baraba K. "Kill all - The Lord will recognize his own!" [E. source]. The Ukrainian Week. 2018. Access Mode: https://m.tyzhden.ua/column/221715

3. EU Declaration on the 5th Anniversary of the Annexation of Crimea: Strong Support for Ukraine and Requirements for the Russian Federation [E. source]. Ukrayinska Pravda. 2019. Access mode: https://www.pravda.com.ua/news/2019/03/17/7209413/

4. Drohomiretsky B. Nemtsov and the puppet [E. source] Ukrayinska Pravda. 2015. Access Mode: https://www.pravda.com.ua/columns/2015/03/3/7060316/

5. Zagnitko A. P. Modern linguistic theories: Monograph. - Ed. 2nd corr. and suppl. - Donetsk: DonNU, 2007. - 219 p.

6. Panchenko V. Shevchenko vs Putin. Liberation Paranoia [E. source]. The Ukrainian Week. 2014. Access Mode: https://tyzhden.ua/Columns/50/104210

7. Petrovets O. Putin's greatest fear is becoming a reality [E. source]. Ukrayinska Pravda. 2017. Access Mode: https://www.pravda.com.ua/columns/2017/03/29/7139629/

8. Petsuk M. Why do Ukrainian journalists go to the occupied Donbass? [E. source]. Ukrayinska Pravda. 2016. Access

\section{RENCES}

\section{Mode:}

https://www.pravda.com.ua/articles/2016/05/17/7108674/

9. About Salary, or "Stingy pays double" [E. source]. Ukrayinska Pravda. 2016. Access Mode: https://www.pravda.com.ua/columns/2016/10/31/7125340/

10. Selivanova O. O. Contemporary linguistics: directions and problems: a textbook/O.O. Selivanova. - Poltava: Environment-K, 2008. - $712 \mathrm{p}$.

11. Solonko O. How the information sump absorbs us [E. source]. Ukrayinska Pravda. 2018. Access Mode: https://www.pravda.com.ua/columns/2018/12/21/7201899/

12. The US unveiled the plan to confront the Russian Federation and China in Africa [E. source]. Ukrayinska Pravda. 2018. Access

Mode: https://www.pravda.com.ua/news/2018/12/15/7201318/

13. Ukraine has submitted to the UN a draft resolution on Crimea, the Russian Federation is against [E. source]. Ukrayinska Pravda. 2016. Access Mode: https://www.pravda.com.ua/news/2016/11/9/7126227/

14. Shumilin O. Lutsenko in the Rada ran over Sobolev: "A young man who has brain diarrhea" [E. source]. Ukrayinska Pravda. $2018 . \quad$ Access Mode: https://www.pravda.com.ua/news/2018/11/6/7197408/

\section{Types of reference in expressions of condemnation \\ Yu. V. Kovalenko}

Abstract. The article identifies and analyzes types of reference of the object of condemnation in the media texts. Based on the socialpsychological criteria of deviance, the types of reference of the subject of condemnation are identified and analyzed. Based on the examples of texts from modern Ukrainian online publications it was investigated language units that represented explicit and implicit reference. Syntax tools that can be used in expressions of condemnation are also discussed.

Keywords: types of reference, condemnation, media text, explicit reference, implicit reference. 